\title{
Isotopic reconstruction of Proboscidean habitats and diets on enigmatic island of Sulawesi
}

\author{
Mika R. Puspaningrum ${ }^{1,2}$, Allan R. Chivas, ${ }^{2,3}$, Iwan Kurniawan ${ }^{4}$, Unggul P. \\ Wibowo ${ }^{4}$, Yahdi Zaim ${ }^{1}$, and Gerrit D. van den Bergh ${ }^{2}$ \\ ${ }^{1}$ Paleontology and Quaternary Geology Research Group, Bandung Institute of Technology, \\ Indonesia \\ ${ }^{2}$ School of Earth, Atmospheric \& Life Sciences, University of Wollongong, Australia \\ ${ }^{3}$ Department of Earth Sciences and Sprigg Geobiology Centre, The University of Adelaide, \\ Australia \\ ${ }^{4}$ Geological Museum Bandung, Badan Geologi, Indonesia
}

\begin{abstract}
Sulawesi is known for its complex geological and biogeographic history, which is reflected in their extinct and extant faunal assemblage. Evidence of oldest terrestrial fauna in Sulawesi was found in the Early Pleistocene sediment and evolved since then. Despite being mostly isolated from the mainland Southeast Asia; four successive Proboscidean taxa have been found from the southern part of the island. The four taxa are: Stegoloxodon celebensis, Stegodon sompoensis, Stegodon sp. B, and cf. Palaeoloxodon namadicus, in which respective taxa are included in successive faunal stages. The aim of this research is to reconstruct the diet and paleoenvironment of these Proboscidean taxa by incorporating stable isotope analysis with the fossil faunal record, geology, and stratigraphy. Stable carbon $\left(\delta^{13} \mathrm{C}\right)$ and oxygen $\left(\delta^{18} \mathrm{O}\right)$ isotope analysis were especially used in this study. Our result suggests that Stegoloxodon celebensis and Stegodon sompoensis were flexible feeders and were able to adapt to different niches, from closed canopy forest to open vegetation, while the diets of Stegodon sp. B, Celebochoerus heekereni and cf. Palaeoloxodon namadicus suggest that they were more specialized.
\end{abstract}

Keywords: Proboscidean, Sulawesi, Pleistocene biogeography, stable isotope analysis.

\footnotetext{
Copyright (C2021. FOSI. All rights reserved.

A Special Publication of abstracts and extended abstracts from the conference in honor of the retirement of Prof. Yahdi Zaim, IPU (22-23 March 2021).
}

DOI: $10.51835 /$ bsed.2021.47.3.364 